\title{
Research on Temple' Role in the Divorce of Edo Japan Basing on Analysis of Enkiridera
}

\author{
Wang Weixing ${ }^{1}$ \\ ${ }^{1}$ School of Foreign Languages, Qingdao University of Science and Technology, Qingdao, Shandong, China \\ Correspondence: Wang Weixing, School of Foreign Languages, Qingdao University of Science and Technology, \\ Qingdao, Shandong, 266061, China. E-mail: luckywwx@163.com
}

Received: May 24, 2016 Accepted: June 13, 2016 Online Published: July 7, 2016

doi:10.5539/ass.v12n8p260

URL: http://dx.doi.org/10.5539/ass.v12n8p260

\begin{abstract}
Edo Japan is male-dominating age. The husband owned the right of divorce, while the wife didn't, the wife could only be at the mercy of their husbands. If the husband wanted to divorce, they just need to give their wives a piece of "Mikudarihan", which was the certificate of divorce at that time, while the wives didn't have the right of asking divorce. That was a well-rounded argument. In fact, about divorce, the wives were not so completely passive, the wives themselves also could actively divorce, and obtained divorce by some means, for example the wife could run into Enkiridera. Enkiridera was a kind of temples in which women seeking release from marriage could take refuge and obtain divorce by the help of the temples. The existence of Enkiridera gave wives a possibility of obtaining divorce.
\end{abstract}

Keywords: Enkiridera, temple law divorce, mediation divorce

Japan's Edo period is an era with the most complete feudal system in Japan history. In the Edo period, women were naturally under the oppression of the feudal system and absolute patriarchal oppression. The women had no freedom of marriage, and had no say in the divorce. Men could divorce the women as they wished while the women could not divorce the men according to their will for women didn't have the right to divorce. When a man wanted to divorce his wife, just gave his wife a paper divorcement and the wife was not entitled to resist. However, if the wife wanted to divorce, she was unable to achieve the desire of divorce if the husband did not agree. This is a general introduction, so is it really true? Did the Women really don't have a way to achieve the desire of divorce? The answer is negative. In fact, fleeing into Enkiridera and obtaining divorce under the auspices of Enkiridera was an effective way. So, what kind of organizations the Enkiridera was? How did Enkiridera help women realize the desire of divorce?

\section{Enkiridera and Its Historical Formation}

Enkiridera is a kind of nunnery. In Japan Edo period, women may flee there in order to achieve desire for divorce. With the help of the nunnery, the woman could achieve desire to divorce. This kind of temple was known as "Enkiridera". There were mainly two such temples in the Edo period: Tokeiji and Mantokuji. The divorce agreement would effect after the woman who fled into the temple had been grounded for a period of time. "Enkiridera" is also called "Kakekomidera". Usually, the husband wrote a certificate of divorce to the wife and the divorce realized. When the wife wanted to divorce but the husband refused to sign the certificate of divorce, the divorce was difficult to obtain. So, as an unusual means to obtain divorce, many wives fled into Enkiridera to seek help. Because the temple had the function of refuge originally, and due to historical reasons, Enkiridera was also generally considered to have the function of refuge from being assaulting by the husbands for the wives who want to divorce. Of course, in the patriarchal society, women who wanted to divorce also needed to pay a price, that is, the woman must be grounded in temples for about three years. Usually, Enkiridera helped women to divorce by two ways: one way was forcing her husband to sign and hand over the certificate of divorce by using the temple laws, which was known as "temple law divorce". Another way was mediating between the two sides, which was known as "mediation divorce".

Why did the Enkiridera have this kind of power? Did other temples also have such power? Here we need to emphasize that in the Edo period, the temples which owned "Enkiridera" privilege actually were only two temples: Tokeiji in Soshu Kamakura and Mantokuji in Joshu Seta, while other temples were deprived of such privilege. Originally, every temple had the function of refuge. The woman who wanted to divorced fled into 
nunneries and obtained divorce after three years of being grounded, which had become a habit in history. The reason why the nunneries have this function was mainly because the man could not enter the nunneries.

With the perfecting of Edo Bakufu domination system, the temple' privilege of refuge was gradually deprived. Bakufu specially formulated "Sect Law" to manage the temples. But Because of having a close relation with Senhime who was the granddaughter of Tokugawa Ieyasu in the history, Tokeiji and Mantokuji retained the privilege. Tokeiji was built in the Kamakura period, which was a nunnery of Rinzai School. The builder is Kakusan $\mathrm{Ni}$ who was the wife of ruler Hojo Tokimune at that time. The formal name of the nunnery was "Shokozantokeisojizenji". The abbot became Tenshu Ni (Concubine Narita Clan of Toyotomi Hideyori) in Edo period when it prospered again. After the "Siege of Osaka", she survived with difficulty and entered Tokeiji as adopted daughter of Senhime. When Ieyasu asked her if she had any wishes, Tenshuni answered that as a nun, she had no other request but continuing the temple laws which began from its building. Ieyasu agreed the request and so Tokeiji had the privilege of "Enkiridera". And Mantokuji was also built in Kamakura Era, which was a nunnery of Jishu Sect. The founder was the woman of Tokugawa Yoshiki, its formal name is "Tokugawa Mantokuji". The founder of Mantokuji is regarded as the ancestors of Leyasu Tokugawa. Later, Senhime, the granddaughter of Ieyasu, fled into this temple from Osaka City. Therefore, the marriage between Tokugawa family and Toyotomi family broke up. Senhime later remarried Honda Clan. As a result of this precedent, Mantokuji became Enkiridera which allowed remarry. In short, the two temples retained the privilege of Enkiridera both because of the relationship with Tokugawa Bakufu.

\section{The Role of Enkiridera in the Process of Divorce}

From the process of Enkiridera helping women to divorce, we can see there were two solutions: one was mediation divorce which was conducted by mediating; the other was temple laws divorce which was conducted by the temple laws. For mediation divorce, the temple mediated between the husband and the wife as an agency, which helped the woman obtain divorce without being grounded in the temple for three years. The temple laws divorce was obligatory in which the temple used the temple laws force the husband hand over the certificate of divorce on condition that the woman must be grounded in the temple for three years. In a sense, the Enkiridera can be looked as a kind of government office; it was a court which judged divorce case. Generally speaking, temples were not willing to force the husband to divorce by using the temple law. The temple would mediated first, if the mediation was invalid, the temple would have to force the husband to divorce by using the temple law. From the cases, we can see in the actual operation, at first, most of the cases were "temple law divorce". But with the changes of society, the proportion of "mediation divorce" increased substantially. The reason for this change was that refuge function of temples was declining, in the meantime, it also meant the system and function of Enkiridera was known by more and more people. It was well-known that once the wife fled into the Enkiridera, the husband had no other choice not agreeing to divorce. So the husband agreed to divorce quietly before the Enkiridera used the temple law.

We will analyze the role of Enkiridera in the actual divorce cases through the following two temples.

As Enkiridera, Tokeiji owned the privilege of judging divorce cases by using Enkiridera law. But the temple would not force the man to divorce the woman just after the woman fled into the temple for help. Commonly, the temple would mediate first, and tried to make the divorce become a mediation divorce. If the mediation failed, the temple would use Enkiridera law as a last mean to force the man to sign the certificate of divorce and order him to divorce.

First, once a woman ran into the temple for help, the temple would conduct an investigation, then asked her mother's side of family to the temple. The temple would ask the father of the woman to persuade her to come round and try not to divorce. If the woman insisted on divorce, her father would negotiate with her husband and tried to get the husband's agreement. If the man agreed, the agreement divorce was established. Sometimes, the woman's father would negotiate with the husband before the temple asked him to do so, and the agreement was established successfully, this situation was called as the "Divorce behind Closed Doors". At this time, the woman's family could bring the woman back directly from the temple by carrying the certificate of divorce sighed by the husband. If the husband did not agree, the woman would ask the temple to force the husband divorce by using the temple law. At this time, the temple would send officials to the husband's house. There were cases that the husband was out and not home if the temple sent officials to his house without notice. The temples usually sent a letter to the mayor who was head of the village, noticing in advance arrival date of the official and asking him to keep the husband home, which is called "official notice".

Apparently, the notice gave the arrival time of Tokeiji's officials, it actually had another secretly purpose, that was hinting to the husband that the matter was not negligible, and hoping the husband to agree to divorce before 
the temple officials arrived, so that to achieve the purpose of "agreement divorce". Communications books and notices of Tokeiji were enveloped in letters of gold chrysanthemum pattern, generally speaking, the man would be scared when they received the communications books or notices, and most would immediately signed a certificate of divorce. This is different from the ordinary agreement divorce, and was known as "divorce agreement after the office notice". Because once temple official arrived, the husband agreed to divorce after reading the "temple law book", the nature of the divorce was changed from agreement divorce to temple law divorce, the woman would be grounded in the temple for three years, it would be a tremendous thing. Therefore, most cases would be conducted behind closed doors in the period of acceptance of official notice. In addition, this kind of agreement divorce would sometimes order the husband to the temple, and achieve the purpose of agreement divorce by persuading and lobbying the husband.

The following two cases show the specific process that Tokeiji conducted the divorce.

Case One: Kane, who was a woman lived in Hongou4 fled into Tokeiji in 1850, her husband was infatuated with prostitutes. Kane's clothes were all pawned, which was not enough for the prostitute's fee. Then, the husband battered the wife viciously, and forced the wife to earn money by being a prostitute. The husband even wanted to sell the wife. Kane had no other choice but to leave home, she wanted to negotiate with the husband about the divorce. The husband didn't agree anyway. So, Kane submitted the pleadings to Tokeiji, asking for help to obtain divorce. According to the pleading of Kane, Tokeiji ordered the husband Kanjiro to the temple. Kanjiro refused to sign the certificate of divorce, and even claimed to sell the wife to get money for prostitution. Being furious with the husband's behavior, the father of Kane asked the Tokeiji to force the husband to divorce.

Then the government office notified the enforcement day to the mayor of village which the husband Kanjiro lived in. In response, when the enforcement document of the temple issued, Kanjiro claimed that he had submitted the pleading to the local officials and asked the local officials to get his wife back. The husband pleaded to the local officials that the wife stole 5000 Japanese Mon of the family, and had an affair with a man named Kinjiro, ran away from home with a coat of the husband and so on, Which resulted in that the local officials could not ask him a to sign the certificate of divorce according to the Tokeiji law immediately. Kane was ordered to confront with the husband. The local officials asked to extradite Kane, but the Tokeiji refused anyway. Eventually, Kane was extradited to the local officials and was sentenced minor punishment, but divorced with the husband. Tokeiji asked the local officials to send Kane back to Tokeiji with the certificate of divorce signed by the husband just after the punishment was finished, Kane would be free after being grounded two years in the temple.

Case Two: A woman named Asa who lived in Asakusa fled into Tokeiji in 1856. Her husband was Ryosaku who worked in the shop of Yoshibe of Komagata. There was an episode before Asa fled into Tokeiji. Earthquake happened in Edo Area in October of 1855. The house of Ryosaku fell down and was burnt. A carpenter named Urajiro repaired the house. Asa had an affair with Urajiro who was maybe a single. Of course, Ryosaku got angry. The husband turned a blind eye because of Urajiro's help and care to his family. But, the wife aggravated him by asking a divorce. Although the husband knew that the wife had an affair with Urajiro, his hate did not get to the point of divorce and he refused to divorce. The wife packed and returned to her mother's family and negotiated with the husband about divorce by matchmaker Jihey. During the period of negotiation, Asa fled into Tokeiji directly, this astonished Ryosaku who knew nothing at all. Maybe the husband battered the wife which resulted in that the wife had sympathy with the carpenter and had an affair with carpenter. Of course, if Asa really had an affair with the carpenter, Tokeiji would not help her. But at last, Tokeiji helped her to obtain divorce.

From the above cases, we can see: first, the means that the temples mainly used when they helped the woman who fled into the temples for divorce was mediation. Forced divorce by temple law was the last means. Before the enforcement measures were taken, if the husband agreed, the divorce would become mediation divorce. Second, taking women's happiness as a priority. The principle which temples insisted in the process of mediation divorce or judgment divorce was defending the happiness of women. In the case of Kane, though Kane also took some responsibilities, but if there was no judgment divorce, Kane would be sold into brothel after she returned home. Asa was as well as Kane. Although Asa was on suspicion of having an affair, Tokeiji helped her to obtain divorce for her happiness. Also there was the case that a sick wife wanted to divorce considering her husband, which the husband disagreed. The wife also went to Tokeiji, and finally obtained divorce, presided by the temple.

Although Enkiridera could help the woman to obtain divorce, the process was not always going smoothly, which may need complex negotiation. In case 1, although Kane realized the desire, she was also punished by the officials. That is to say, women also need to pay a price for obtaining divorce. When the husband disagreed and divorce was temple law divorce, the condition of divorce was grounded in Enkiridera for three years. The 
woman had to be grounded for three years although she was innocent. Thus, we can see that the woman in Edo period would be punished when she wanted to divorce; even "Enkiridera" was not an exception. When the divorce was mediation divorce, although the husband was pressed by "Enkiridera", the divorce also needed the agreement of the husband, which asserted patriarchal authority.

The situation that "Mantokuji" participated in the divorce was similar with "Tokeiji". But, also had its own features, which are "Agreement Divorce within the Year" and "Hangengakae".

Agreement Divorce within the YearMantokuji also mediated first and sentenced divorce according to the temple law if the mediation failed. Generally, mediation divorce presided by the temple would benefited both sides. But once the mediation failed, the temple would had to use Enkiridera Law, and forced the two sides divorce by using the official background of Enkiridera, the two sides would both pay a price for divorce, the woman would had to be grounded in the temple for 25 months and lived a life of nun. During this period, the woman could not remarry accordingly, and the man also could not remarry. However, during the period, if the man could not hold on for some reasons, such as he had to bring up the children himself, he would be confined by the livings, or he had other proposal, his attitude may soften and sign the certificate of divorce, he would agree to divorce, and the temple would conduct at this time. This was also considered as mediation divorce, and the divorce was valid. The woman then could leave the temple immediately and remarry. The man could also remarry, this was called "Agreement Divorce within the Year", that is agreement divorce at any time.

Hangengakae. There is also a special situation called Hangengakae, it was a special temple law of Mantokuji, while Tokeiji had not. The so called "Hangengakae" is that considering the special circumstances of the woman, the limit that the woman must be grounded for 25 months could be reduced to 12.5 months after obtaining divorce according to the temple law. The special circumstances were mainly two circumstances: one is the two sides just engaged and did not marry yet, the woman wanted to break off their engagement; the other is the woman who wanted to divorce were not wife but concubine. That is the concubine wanted to dissolve the marriage with the husband. For example, in 1838, Matsu, who was the sister of Heisaburo wanted to break off the engagement suddenly, and fled into Mantokuji, while her future husband did not agree, Matsu finally dissolved the engagement after being grounded in the temple for 12.5 months.

\section{Why "Enkiridera" Had the Power of Forcing Divorce}

The system of "Enkiridera" was a kind of residue of refuge function of temple. The temple has the function of refuge naturally, for it is pure and compassionate place which delivers all the beings for torment and forbid killing. The people who were chased after to kill would get refuge when they ran into the temple. People who were close to starvation would get handout when they ran into the temple. Even the common people sometimes would get free vegetarian food when we walk into the temple. Chinese temples have been like this from ancient time, and so have the temples of Japan. The nunnery would especially take more effort to help the women. It was natural to give refuge for the women who ran into the temples and help them to obtain divorce.

In medieval Japan, the temple was powerful. Some powerful temple even could compete with the secular power, so the refuge function of the temple was very powerful. A lot of exiles、 refugees even the criminals had run into the temples to seek refuge. The temple took advantage of their authority and the principle that Buddhism is sacred to prevent hunting from secular power and give shelter for the refugees.

In medieval Japan, the temple which function of refuge was most powerful was Konggobuji of Koyasan. The temple even had a special room to give shelter for refugees, which was called Tankaya. It was a room for absorbing fugitives. No matter how serious crime the fugitive committed, he would escape form punishment and obtain life safety as long as he fled into the temple. So a lot of fugitives, even many political prisoners fled into the temple. Just in 1595, since Toyotomi Hidetsugu committed suicide after fleeing here, the Tankaya function of refuge began to weaken, and disappeared completely by the early time of Edo period

The ability of refuge reflected the real power. In Sengoku period, warlords contended for hegemony and countries strived with each other. The temple established a powerful armed organization Sōhei. The ability of refuge was more and more powerful. But the function of refuge violated the dignity of secular power, and was disgusted and opposed by secular power accordingly. With the ending of Sengoku period and the unification of Japan society, the ability of refuge of the temples was greatly limited and diminished step by step.

The system of Enkiridera which protected woman's right was also diminished and even abolished. Finally, only two temples retained the function of refuge, which were Tokeiji and Mantokuji. As previously mentioned, the reasons that the two temples retained the system of Enkiridera, was that the two temples were both associated with Senhime, which was the granddaughter of Leyasu Tokugawa who was the highest ruler of Japan at that 
time.

Tokeiji was established in the Kamakura period, several abbots of Tokeiji were noble. Mantokuji, as mentioned earlier, Senhime who was granddaughter of Leyasu Tokugawa had been lived in the temple and remarried Honda clan later. In view of this relationship, Mantokuji had also established Enkiridera law which permitted to remarry. Other temples had been deprived of this power because they did not have such origins.

We can see that Enkiridera system is only a microcosm of weakening process of temples refuge function. All the nunneries had the function of refuge originally, there were only two temples retained the function with the development of Japan society. In the original nunneries, the woman could ask for a divorce if she ran into the nunneries and lived as a nun for three years. It was clear that one should not have the marriage if she becomes a nun, accordingly she could obtain divorce. Leaving the temple meant resuming the secular life. The woman could remarry after leaving temple. It was a traditional practice that a woman who hated her husband could obtain divorce if she was willing to cut her hair and be a nun for three years in nunneries, this practice was also permitted by the officials. All the nunneries had such function. But, originally, when the nunnery conducted the temple law divorce, the women obtained divorce just after she was grounded in the nunneries for three years and did not need the husband to sign the certificate of divorce. Only after the Enkiridera system was retained by the two temples, the divorce asked the woman must be grounded for enough time and the certificate of divorce signed by the husband was also necessary. It is thus clear that, in order to keep Enkiridera system, Enkiridera made some concessions to cater to the secular system.

It must be said that, not only nunneries, but also other kinds of temples shrine and so on were all had the similar function. According to the survey data of the writer, temples of Edo period near Yamanosiri village had ever actively participated in divorce dispute of local villagers. According to $<<$ Village head diary of Yamanosiri $>>$, Rinshoji, a temple located in Yamanosiri village, had participated in divorce mediation of local villagers for 9 times. When the divorce negotiations got bogged down, the officials of the villages which men and women lived in would choose Rinshoji as negotiation venue. Presiding and mediating by the temple, the divorce dispute would be solved broadly. Even there was case that the abbot of the temple participated in divorce mediation directly. For example, Renjoji was another temple near Yamanosiri village, its abbot had actively participated in the divorce of Shinsuke' wife. The divorced couple unexpectedly reunited after the mediation, and even become relatives of this abbot.

\section{Conclusion}

From the above discussion, we can conclude: Enkiridera and other kinds of temples played an important part in the divorce of common people in Edo Japan. Especially when the woman wanted to divorce and the husband disagreed. The Enkiridera would help the woman to obtain divorce by active mediation or even using the temple law, which protected the marriage right of the women and dealt a blow to the absolute right of men to divorce in the patriarchal society, which undoubtedly had a great significance. It can be look as a challenge to the system of divorce in the Edo period. In addition to the Tokeiji and the Mantokuji, although other temples were deprived of the privilege of Enkiridera, they were not completely had nothing with the secular world, on the contrary they also actively participated in divorce dispute of local villagers. Using the advantage that the temple is a place separate from the secular world, the temple played an active role in divorce mediation and tried to protect the happiness of both sides, to deliver all beings from torment.

\section{References}

Gotenba Editorial Board. (1977). Gotenba Editorial Board Village Head Diary of Yamanosiri.

Igarasitomio. (1989). Kakekomiji. Tokyo: Hanawashobo.

Inouezenjo. (1995). Tokeiji and Kakekomi Onna. Yokohama: Yurindo.

Ishiiryosuke. (1965). The Divorce of Edo. Tokyo: Nikkei.

Takagitadasi, M. (1987). Edo Divorce and Women. Tokyo: Heibonsha.

Takagitadasi. (1990). Study of Enkiridera Mantokuji. Tokyo:Seibundoh.

Takagitadasi. (2014). Mikudarihan and Enkiridera edo Divorce Re Interpretation. Tokyo: Yoshikawakobunkan.

\section{Copyrights}

Copyright for this article is retained by the author(s), with first publication rights granted to the journal.

This is an open-access article distributed under the terms and conditions of the Creative Commons Attribution

license (http://creativecommons.org/licenses/by/3.0/). 